\title{
Baseline information development for Energy Smart Schools - applied research, field testing and technology integration
}

\author{
Final Report to NASEO, LBNL-54233 \\ Tengfang Xu and Mary Ann Piette
}

July 23, 2004

\section{Task Scope and Goals}

The original scope of work was to obtain and analyze existing and emerging data in four states: California, Florida, New York, and Wisconsin. The goal of this data collection was to deliver a baseline database or recommendations for such a database that could possibly contain window and daylighting features and energy performance characteristics of Kindergarten through $12^{\text {th }}$ grade (K-12) school buildings (or those of classrooms when available). In particular, data analyses were performed based upon the California Commercial End-Use Survey (CEUS) databases to understand school energy use, features of window glazing, and availability of daylighting in California K-12 schools.

The outcomes from this baseline task can be used to assist in establishing a database of school energy performance, assessing applications of existing technologies relevant to window and daylighting design, and identifying future R\&D needs. These are in line with the overall project goals as outlined in the proposal.

\section{Approaches}

In the past, various studies have been conducted by LBNL researchers (Piette et al. 2001, Kinney et al. 2003) and others (Callahan et al. 1997, KEEP 1998, PG\&E 1999, Hinge et al. 2002) on school energy usage. Some of these studies have generated relevant databases or reports that are publicly available. The general approaches employed in this research project included the following:

- To obtain existing and emerging data and relevant surveys by literature research and communications with staff members working on school programs or school projects in the states of California, Florida, New York, and Wisconsin. Throughout the project, LBNL's outside contacts included staff members from Florida Solar Energy Center (FSEC, FL), Energy Center of Wisconsin (ECW, WI), New York State Energy Research \& Development Authority (NYSERDA, NY), California Energy Commission (CEC, CA), and Collaborative for High Performance Schools (CHPS, CA).

- To conduct reviews of existing survey forms and data information that is available, and to suggest key contents to include in a baseline database. 
- To analyze the California CEUS databases by using SAS TM$^{1}$, a software program for statistical analysis, with the focus on K-12 schools' energy use, window design features, and daylighting availability, and to confirm key contents to be included in baseline databases for future development.

\section{Accomplishments}

The major accomplishments of the baseline data task are data collection and compilation, reviews and analyzes of databases, and database establishment and structure recommendations.

\section{Data Collection and Compilation}

We obtained available information about K-12 school buildings and their energy usage from three states: California, Florida, and Wisconsin. Based upon our communications with NYSERDA, there is no K-12 energy usage information from New York state readily available for inclusion Tables 1 and 2 summarize the available data. Specifically,

- For California, we have reviewed and conducted analyses on the California Commercial End-Use Survey (CEUS) databases. The databases were produced from comprehensive on-site surveys of buildings characteristics. These surveys were sponsored by the California Energy Commission (CEC). The databases used in this project include Pacific Gas \& Electric Company surveys (CEUS - PG\&E 1996), and Southern California Edison company surveys (CEUS - SCE 1992, 1995). Because the energy use reported by PG\&E and SCE was only for the energy use provided by the respective utilities, PG\&E CEUS databases contain both gas and electricity data while SCE CEUS databases contain only electricity use. In addition, geographic coverage for the existing CEUS is limited to the service territories of both utilities. However, as demonstrated by the extensiveness of survey questions, the existing CEUS surveys appear to be the most comprehensive in terms of the depth of contents and the coverage of building sectors. The survey information of about one hundred K-12 schools is contained in the PG\&E and SCE CEUS databases.

- For Florida, we have obtained and reviewed both survey questions and databases conducted by Callahan et al. 1997. The basic statistics are reported in the FSEC report (Callahan et al. 1997). For the purpose of comparison, the total energy use intensity (EUI) and sample information is listed in Table 1 and Table 2.

- For Wisconsin, we have reviewed the survey results that are published on the University of Wisconsin website (1997-98 WEI-2 school survey data reported in http://www.uwsp.edu/cnr/wcee/keep/audit/average.htm). Basic statistics of EUI are listed in Table 1 and Table 2 for the purpose of comparison.

- On the national level, we have reviewed the Commercial Buildings Energy Consumption Survey (CBECS, EIA 2001), a national-level sample phone-survey of commercial buildings and their energy suppliers conducted quadrennially by the Energy Information Administration (EIA, http://www.eia.doe.gov/emeu/cbecs/). Some aggregated information of energy use intensity is listed in Table 1 and Table 2.

${ }^{1}$ SAS Institute Inc., Cary, NC, USA. http://v8doc.sas.com/sashtml/ 


\section{Reviews and Analyses of Databases}

Based upon the reviews and comparisons of available information from school energy information from Florida, Wisconsin, California, and CBECS, it appears that it is important to focus on understanding the strengths and weakness of current databases and to recommend key information to be included in future databases, and that focusing on achieving a new and powerful database that already contains such information would not be practical in this project. Some of the major underlying reasons are:

- Most of the existing databases (e.g., on the state level), if available, are proprietary or at least not publicly available. This would potentially present barriers against creating a comprehensive and powerful database that would later be available for public use.

- The formats of survey and parameters contained in California CEUS and Florida FSEC databases are very different. These difference, plus the small sample sizes of information records in the CEUS databases for California school sector (K-12), makes it less appealing to undertake the effort of combining the two state's databases even if we assume that they could be made available to the public.

\section{Dataset Establishment and Structure Recommendations}

Data on energy usage and design features directly related to "classroom" spaces was virtually non-existent in our investigations. Based upon the California CEUS databases in various utility service territories, we have created combined datasets that contain design features, energy use, and likely factors impacting the energy use in California K-12 schools. These parameters, together with relevant information that should be considered for future database development, are expected to allow further analysis of building energy performance, building characteristics related to windows and daylighting, and the possible correlation between energy performance and daylighting. Specifically,

- We have suggested key features related to window, glazing, and daylighting to be included in a database for K-12 school buildings, and have thus created datasets derived from California CEUS databases for the data analysis of California K-12 buildings.

- The California CEUS databases contain some useful parameters that characterize the window and daylighting design features, and geographical regions. Such information is also used to explore possible correlations among them.

\section{Outcomes}

We have performed the following technical tasks in this baseline task: 1) reviewed what is already contained in the existing databases, and their strengths and weakness for the purpose of investigating energy use and features of window glazing and skylight in K-12 schools; 2) compiled and analyzed the site energy usage of sampled school buildings in three states and on the national level; 3 ) understand window design features and applied technologies (e.g., glazing and skylight) in California CEUS databases; and 4) examine energy use intensity (EUIs) of K-12 school buildings in the California CEUS databases, grouped by window features and availability of daylighting. The efforts in baseline data collection, compilation, reviews, and analysis have 
resulted in recommendations for a list of key parameters to be included in future database development. The specific outcomes are described below.

\section{Existing databases for $\mathrm{K}-12$ school buildings and their strengths and weakness}

\section{1) California CEUS databases}

CEUS is composed of comprehensive databases developed by on-site surveys on buildings characteristics, which were sponsored by the California Energy Commission (CEC). In the past, the surveys were contracted out to the three major California electric utilities: Pacific Gas \& Electric (PGE), Southern California Edison (SCE), and San Diego Gas \& Electric (SDGE). The actual surveys were conducted through on-site interviews performed by companies contracted to the utilities. CEUS has been largely underutilized as it has not been available to the general public. The next CEUS to be released will be conducted by a single contractor and will be made publicly available in some form. More details about CEUS databases are available at http://poet.lbl.gov/calarch/ceus.html.

We analyzed three sets of survey results on energy use and related physical and operational characteristics of California's K-12 schools buildings in the PG\&E and SCE territories.

- For the 1996 PG\&E data, the surveys were collected during 1996 from approximately 1000 building establishments in PG\&E service territory. A total of 47 surveys were identified as K-12 schools, representing less than $0.5 \%$ of the surveyed commercial buildings.

- For the 1992 SCE data, the surveys were collected during 1992 from about 700 building establishments in SCE service territory. According to SCE's stratification methodology, about 300 were allocated to a high-resolution survey and about 400 were allocated to a low-resolution survey. Only 2 of out of the 400 low-resolution surveys were identified as K-12 schools, representing approximately less than $0.3 \%$ of the surveyed buildings (700).

- For the 1995 SCE data, the surveys were collected during 1995 from about 500 building establishments in SCE service territory. This CEUS database mainly includes the following business types: Hotels/Motels, Elementary and Secondary Schools, Colleges and Universities, Hospitals and Clinics, and Miscellaneous Commercial. 57 of the surveys were identified as K-12 schools, representing approximately $10 \%$ of the surveyed commercial buildings.

Compared to other databases examined in this project, the CEUS databases are by far the most comprehensive collection of energy use, building and system characteristics for school buildings. However, there are some limitations to the CEUS databases.

- First, the PG\&E CEUS databases contain both gas and electricity end use data while SCE CEUS databases contain only electricity use data. In another word, none of SCE surveys contain natural gas use data. 
- Second, there are some indications of other fuel energy use in the building, but none of the databases provides quantitative information that can be used to calculate the overall site energy use.

- Third, there is no sub-metered data available to indicate the energy use by classroom spaces.

- Fourth, the overall current sample size of K-12 schools is very small compared to other building types contained in the CEUS surveys. In order to take advantage of the CEUS databases, there is a need to increase survey and audit activities targeted toward K-12 schools in California.

We analyzed each of the survey datasets to create a school energy use profile as well as to identify characteristics that may relate to building energy use. We then combined the survey data from the three sources to create school energy use profiles (with and without swimming pools), including information on building characteristics such as window and glazing features.

2) Florida FSEC database

The Florida FSEC database (Callahan et al. 1997) contains physical and operational characteristics for about 1,300 Florida's public schools, 680 of which have matching utility data. The elementary schools represent the largest total floor area within the Florida school system. The database was used to estimate the total annual energy cost for the Florida school system. The annual total energy costs averaged $\$ 1.24 / \mathrm{ft}^{2}(1996)$, which was twice as much as their counterparts surveyed in Wisconsin (1998). Overall, the FSEC database contains a range of useful information such as energy use, building and system characteristics in school buildings in Florida's schools. The review of the previous work (Callahan et al. 1997) indicates that there are a number of key parameters that could impact the annual EUI of these schools:

- Floor area, number of students and faculty, operation schedule (monthly, weekly, non-school days)

- School type (e.g., high school, middle school, vocational school, and elementary school; portable classrooms vs. regular classrooms)

- Availability of windows, thermostats, humidity problems, manual lighting, clock thermostat controls, central cooling set points, ceiling fans, operable windows, demand controlled ventilation, light colored roofs, heat pump; HVAC type (e.g., packaged cooling equipment vs. central chillers)

The overall school sample size with valid utility data is about 680 , including elementary, middle, high, vocational schools and community colleges in Florida. The actual sample size of the K-12 schools is expected to be smaller.

There are several limitations of the existing database:

- Although the FSEC database contains monthly utility billing records that includes electricity, natural gas, oil, and propane, there is no sub-metered data available to indicate the energy use by classroom spaces. 
- There were some indications of the availability of window and glass types (i.e., tinted or solar control) but there was no additional information on other window features that could be used to analyze the design features. This indicates that in order to further explore possible relationships between classroom energy use and window and daylighting designs, there is a need to enhance the survey and audit activities for the Florida schools.

\section{3) CBECS database}

In the 1999 Commercial Buildings Energy Consumption Survey (CBECS, EIA 2001), buildings are classified according to principal activity. The 1999 CBECS database was developed mainly by employing phone surveys and statistical extrapolation. It contains aggregated information on "education" types of buildings, as well as for other commercial buildings. The education building is defined to be used for academic or technical classroom instruction, such as elementary, middle, or high schools, and classroom buildings on college or university campuses. We used the 1999 CBECS data in table format for the analysis in this report.

The "education" building database does not differentiate K-12 from other educational buildings although the phone survey includes the following sub-categories with more specific activities: preschool or daycare, elementary, middle or high school, and college or university. Therefore, the strengths of the database include its large sample size, its wide geographical coverage representing the US, and its specific inclusion of classroom floor spaces. The main disadvantage is that the database contains the aggregated information that also includes colleges. This means it is not a straightforward task to estimate the data for K-12 schools. On the other hand, buildings on education campuses for which the main use is not classroom are included in the category relating to their use. For example, administration buildings are part of "Office," dormitories are "Lodging," and libraries are "Public Assembly."

A selective list of parameters contained in the current CBECS database is being used by the Energy Star model (EPA). The current model considers input from the following parameters:

- gross floor area

- number of months in use

- number of personal computers (PCs)

- number of students

- weekly operating hours

- $\%$ of space air conditioned, $\%$ of space heated

- on-site cooking facilities $(\mathrm{Y} / \mathrm{N})$

- mechanically ventilated $(\mathrm{Y} / \mathrm{N})$

The 1999 CBECS database also contains building shell conservation features that are relevant to windows, i.e., layers of glazing and types of glazing (tinted, reflective, 
shading glass), but it does not contain the types of other glazing information that are seen in the California CEUS databases.

\section{Site energy usage of sampled school buildings in three states and on the national level}

The principal site energy usage metric is the energy used per square foot of total school building floor area, or energy use intensity (EUI). Annual EUI is the annual energy use (kBtu) divided by the building floor area $\left(\mathrm{ft}^{2}\right)$ of concerns. We calculated the annual energy use intensity $\left(\mathrm{kBtu} / \mathrm{ft}^{2}\right)$ for electricity and natural gas usage, and sum of these based upon the total school floor area contained in the California CEUS databases. The results are shown in Table 1, Table 2, and Table 3. For instance, Table 1 shows statistics of electricity use intensity in buildings, including all-electricity and mixed-fuel use building types.

For comparison, similar metrics reported from other states (Florida and Wisconsin) are listed in the tables when they are available. For informational purposes, selective statistics of energy end-use by "Education" type of buildings, which include K-12 schools and colleges, from the 1999 Commercial Buildings Energy Consumption Survey (CBECS) are also exhibited in the tables. The tables contain various EUI values calculated or reported based upon the databases from three states and the CBECS.

Based upon the limited sample size in the California data, the electricity EUI varies from 2.6 $190.5 \mathrm{kBtu} / \mathrm{ft}^{2}$ (among 106 samples) with a median of $23.8 \mathrm{kBtu} / \mathrm{ft}^{2}$, while the natural gas EUI varies from $6.2-108.7 \mathrm{kBtu} / \mathrm{ft}^{2}$ (among 37 samples) with a median of $24.6 \mathrm{kBtu} / \mathrm{ft}^{2}$. The EUI is based upon total floor areas of the school buildings. The existing CEUS databases contain some information about the percentage of classroom floor areas as compared to the total building floor areas in the K-12 schools. However, such data information collected by CEUS surveys is not consistently available, therefore it is not reported in this report. In addition, it is clear that there is no energy use data break-down for classroom areas. The existing energy information is insufficient to reasonably estimate the EUI of classroom spaces for the surveyed K-12 schools in California. 
Table 1 School Energy Use Intensity (electricity)

\begin{tabular}{|c|c|c|c|c|c|c|}
\hline \multirow[b]{3}{*}{$\begin{array}{l}\text { Energy Use and } \\
\text { Floor Areas }\end{array}$} & \multirow[b]{3}{*}{ Statistics } & \multicolumn{4}{|c|}{ State } & \multirow{2}{*}{\begin{tabular}{|c|} 
National \\
CBECS (Education
\end{tabular}} \\
\hline & & CA & FL & NY & WI & \\
\hline & & $\begin{array}{c}\text { electricity energy use per } \\
\text { square foot of school } \\
\text { building floor area }\end{array}$ & - & - & $\begin{array}{c}\text { electricity energy use per } \\
\text { square foot of school } \\
\text { building floor area }\end{array}$ & $\begin{array}{l}\text { electricity energy use } \\
\text { per square foot of } \\
\text { classroom floor area }\end{array}$ \\
\hline \multirow{4}{*}{$\begin{array}{c}\text { Statistics of EUI } \\
\left(\mathrm{kBtu} / \mathrm{ft}^{2} \mathrm{Yr}\right)\end{array}$} & Median & 23.8 & - & - & 18.8 & 22.5 \\
\hline & Mean & 37.6 & - & - & 20.8 & 29.7 \\
\hline & Max & 190.5 & - & - & - & - \\
\hline & Min & 2.6 & - & - & - & - \\
\hline \multirow{2}{*}{$\begin{array}{l}\text { Building Size - } \\
\text { Floor Area }\left(\mathrm{ft}^{2}\right)\end{array}$} & Median & 40,131 & - & - & 57,904 & 8,000 \\
\hline & Mean & 63,210 & - & - & 76,057 & 26,456 \\
\hline Schools & Total number & 106 & - & - & 917 & 327,000 \\
\hline
\end{tabular}

Sources:

CA: CEUS databases supplied by CEC from PG\&E surveys (1996), and Southern California Edison surveys (1992, 1995)

WI: 1997-98 WEI-2 school survey data reported in http://www.uwsp.edu/cnr/wcee/keep/audit/average.htm

1999 CBECS: http://www.eia.doe.gov/emeu/cbecs/

Table 2 School Energy Use Intensity (natural gas, or others if specified)

\begin{tabular}{|c|c|c|c|c|c|c|}
\hline \multirow[b]{3}{*}{$\begin{array}{l}\text { Energy Use and } \\
\text { Floor Areas }\end{array}$} & \multirow[b]{3}{*}{ Statistics } & \multicolumn{4}{|c|}{ State } & \multirow{2}{*}{\begin{tabular}{|c|} 
National \\
CBECS (Education
\end{tabular}} \\
\hline & & CA & FL & NY & WI & \\
\hline & & $\begin{array}{c}\text { Natural gas energy use } \\
\text { per square foot of school } \\
\text { building floor area } \\
\end{array}$ & - & - & $\begin{array}{c}\text { fossil fuel and wood } \\
\text { energy use per square foot } \\
\text { of school building floor } \\
\text { area }\end{array}$ & $\begin{array}{c}\text { Natural gas } \\
\text { consumption }\left(\mathrm{ft}^{3}\right) \text { per } \\
\text { square foot of } \\
\text { classroom floor area } \\
\end{array}$ \\
\hline \multirow{4}{*}{\begin{tabular}{|c|}
$\begin{array}{c}\text { Statistics of EUI } \\
\left(\mathrm{kBtu} / \mathrm{ft}^{2} \mathrm{Yr}\right)\end{array}$ \\
\end{tabular}} & Median & 24.6 & - & - & $52.2 *$ & $25.0 * *$ \\
\hline & Mean & 30.7 & - & - & $55.6^{*}$ & $33.5 * *$ \\
\hline & $\operatorname{Max}$ & 108.7 & - & - & - & - \\
\hline & Min & 6.2 & - & - & - & - \\
\hline \multirow{2}{*}{$\begin{array}{l}\text { Building Size - } \\
\text { Floor Area }\left(\mathrm{ft}^{2}\right)\end{array}$} & Median & 37,434 & - & - & 57,904 & 8,000 \\
\hline & Mean & 54,546 & - & - & 76,057 & 29,200 \\
\hline Schools & Total number & 37 & - & - & 917 & 225,000 \\
\hline
\end{tabular}

Sources:

CA: CEUS databases supplied by CEC from PG\&E surveys (1996), and Southern California Edison surveys $(1992,1995)$

WI: 1997-98 WEI-2 school survey data reported in http://www.uwsp.edu/cnr/wcee/keep/audit/average.htm

*: The unit reported on the website was originally "mBtu/ft2," which is corrected here as "kBtu/ft2" on the annual basis

**: The unit is in $\mathrm{ft} 3$ natural gas per $\mathrm{ft} 2$ of classrooms, but the actual $\mathrm{kBtu} / \mathrm{ft} 2$ value maybe obtained by multiplying a factor somewhere between

0.5 to 1.5

1999 CBECS: http://www.eia.doe.gov/emeu/cbecs/ 
Table 3 School Energy Use Intensity (aggregated)

\begin{tabular}{|c|c|c|c|c|c|c|}
\hline \multirow[b]{3}{*}{$\begin{array}{l}\text { Energy Use and } \\
\text { Floor Areas }\end{array}$} & \multirow[b]{3}{*}{ Statistics } & \multicolumn{4}{|c|}{ State } & \multirow{2}{*}{\begin{tabular}{|c|} 
National \\
CBECS (Education) \\
\end{tabular}} \\
\hline & & CA & FL & NY & WI & \\
\hline & & $\begin{array}{c}\text { sum of electricity and } \\
\text { natural gas use per square } \\
\text { foot of school building } \\
\text { floor area }\end{array}$ & \begin{tabular}{|} 
total energy use per \\
square foot of air \\
conditioned floor area
\end{tabular} & - & $\begin{array}{l}\text { total energy use per } \\
\text { square foot of school } \\
\text { building floor area }\end{array}$ & $\begin{array}{l}\text { total energy use per } \\
\text { square foot of } \\
\text { education floor area }\end{array}$ \\
\hline \multirow{4}{*}{$\begin{array}{c}\text { Statistics of EUI } \\
\left(\mathrm{kBtu} / \mathrm{ft}^{2} \mathrm{Yr}\right)\end{array}$} & Median & 45.2 & - & - & - & - \\
\hline & Mean & 59.2 & 68.0 & - & - & 75.0 \\
\hline & Max & 215.0 & 226.0 & - & - & - \\
\hline & Min & 27.0 & 2.0 & - & - & - \\
\hline \multirow[b]{2}{*}{$\begin{array}{l}\text { Building Size - } \\
\text { Floor Area }\left(\mathrm{ft}^{2}\right)\end{array}$} & Median & 37,434 & - & - & - & 8,000 \\
\hline & Mean & 54,546 & $\begin{array}{c}98,900 \text { (Gross) } \\
87,151 \text { (AC) } \\
\end{array}$ & - & - & 26,456 \\
\hline Schools & Total number & 37 & 654 & - & - & 327,000 \\
\hline
\end{tabular}

Sources:

CA: CEUS databases supplied by CEC from PG\&E surveys (1996), and Southern California Edison surveys (1992, 1995)

FL: FSEC report (Callahan et al. 1997), the numbers may include other fuel usage

1999 CBECS: http://www.eia.doe.gov/emeu/cbecs/

\section{Window design features and applications based upon California CEUS}

The key parametric design features relevant to window glazing and skylight in the California CEUS databases include the following:

- Glazing layer

- Glazing types (tinted, reflective, clear)

- Glazing feature (gas-filled, low-e)

- Window frame (wood, metal, etc.)

- Interior shading $(\mathrm{Y} / \mathrm{N})$ and types (fixed, movable, none)

- Exterior shading $(\mathrm{Y} / \mathrm{N})$

- Skylight $(\mathrm{Y} / \mathrm{N})$

The California CEUS databases generally contains this information but the surveys for different utility territories (i.e., PG\&E vs. SCE) may have different ways of asking the questions. The basic statistics for these characteristics are presented in Appendix A - Design features relevant to window glazing and skylight (CEUS). The following summarizes the major characteristics of window, glazing, and shading in these K-12 schools.

\section{Window and Glazing}

Among the 105 K-12 schools located in PG\&E and SCE territories:

- most of the schools surveyed (95\%) have single-panes windows. Only $5 \%$ of the schools have double-pane glazing. 
- $57 \%$ have clear glazing, $39 \%$ have tinted glazing, and $4 \%$ have reflective glazing

- $81 \%$ have metal framed windows, $19 \%$ have wood framed windows Shading

- Among 106 K-12 schools located in PG\&E and SCE territories, 33\% of the schools surveyed have exterior shading on windows, and $67 \%$ do not have exterior shading

- Among 45 schools with valid interior shading information in PG\&E service territory, only one of them (2\%) does not have interior shading, while the rest of them $(98 \%)$ do. $82 \%$ have movable shading and $16 \%$ have fixed interior shading. There was no window shading information provided in the SCE surveys.

\section{Skylight}

- Among 47 schools with valid skylight information in the PG\&E service territory, only four of them ( $9 \%$ ) have skylights, while the rest of them (91\%) do not. There was no skylight information provided in the SCE surveys.

\section{Energy use intensity (EUI) of CEUS K-12 school buildings in California.}

A recent report (Piette 2001) based upon the California CEUS datasets indicates that the existence of swimming pools in K-12 schools can significantly increase the overall energy use intensity in schools. Different systems and amenities (such as swimming pools) affect the energy intensity of schools (Hinge et al. 2002). Swimming pool energy consumption could increase the energy use intensity. For this project, we used the SAS statistical program to merge relevant data from the various California CEUS databases to create two datasets, one for all K-12 school buildings with and without swimming pools, and one for all K-12 school buildings without swimming pools.

We first used the "all survey schools' dataset to analyze the school EUI grouped by swimming pools and climate zones. The major findings are presented in Appendix B. For example, the average annual electricity EUI is $33.2 \mathrm{kBtu} / \mathrm{ft}^{2}\left(\mathrm{Std}\right.$. Dev $\left.=35.9 \mathrm{kBtu} / \mathrm{ft}^{2}\right)$ for the 75 schools without swimming pools; while it is $38.1 \mathrm{kBtu} / \mathrm{ft}^{2}\left(\mathrm{Std} . \mathrm{Dev}=31.6 \mathrm{kBtu} / \mathrm{ft}^{2}\right)$ for the $18 \mathrm{schools}$ with swimming pools. One other school with hot tubs had an EUI of $63.0 \mathrm{kBtu} / \mathrm{ft}^{2}$. The annual natural gas EUI also exhibits large variations between the schools without pools (Mean $=26.7$ $\mathrm{kBtu} / \mathrm{ft}^{2}$, Std. Dev. $\left.=17.1 \mathrm{kBtu} / \mathrm{ft}^{2}\right)$ and with pools $\left(\right.$ Mean $=63.4 \mathrm{kBtu} / \mathrm{ft}^{2}$, Std. Dev. $=31.8$ $\mathrm{kBtu} / \mathrm{ft}^{2}$ ). This confirms the premise that schools with pools have higher EUIs than schools without pools. Understanding that energy use by swimming pools in fact skews the overall EUI values for specific schools, we later used the schools without swimming pools dataset to analyze the school EUI and window glazing characteristics.

Figure 1 and 2 show the average electricity and natural gas EUI for schools without swimming pools, "stratified" based on various window, shading, and daylighting features reported in the surveys. The overall sample size is 75 for electricity EUI and 33 for natural gas EUI. Note that the sample sizes used to calculate each of the "stratified" EUI with different categories are usually smaller than 75 (for electricity) and 33 (for natural gas). More details are in Appendix C.

For most parameters examined, we cannot find significant correlations among the school EUI, window features, and climate (geographical) zones (Kinney 2003). It is likely that a combination 
of the following factors would make it almost impossible to draw apparent correlations or to establish cause-effect relationships.

- There are many factors impacting overall energy use of school buildings in the CEUS databases.

- The sample size for the K-12 schools in the CEUS database is statistically too small to be useful for drawing any statistically-sound statements.

- The way the climate zones are divided was consistent with the CalARCH approach (CalARCH), which aggregated CEC 16 climate zones into four regions by geographical locations.

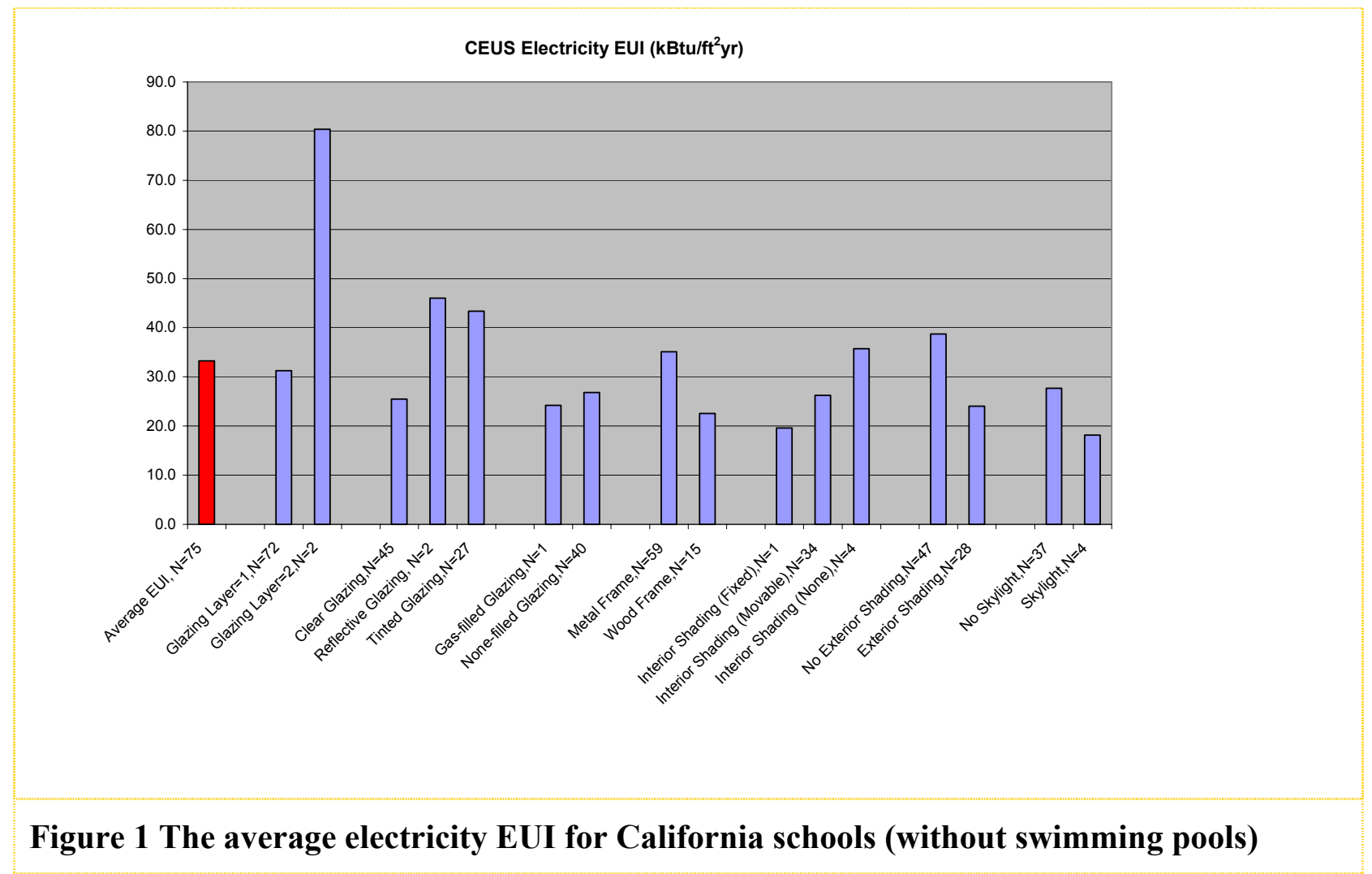




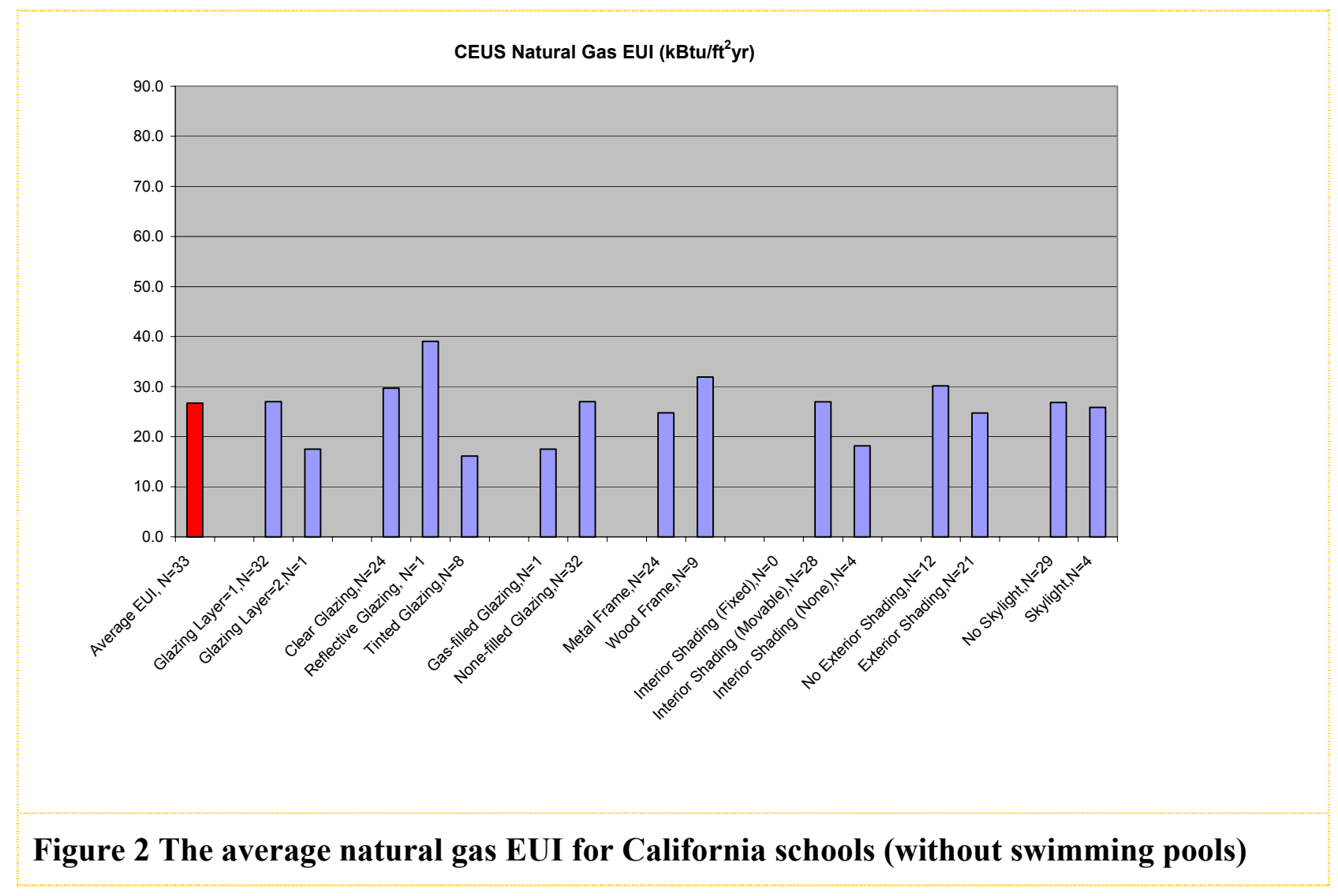

\section{Recommendation for key parameters to be included in future database development}

Based upon the review of existing databases developed on the utility, state, and national levels, and key parameters used in the Energy Star models developed by the EPA, we have found 1) that there is scattered K-12 school data available from utilities and some states such as Florida and California; and 2) that CBECS appears to be the best identified to contain similar information on the national level, but that it only contains aggregated data with other educational facilities, e.g., university and college buildings. Specifically,

- Energy Star: Key inputs to a new Energy Star model being developed by EPA for K-12 schools include the following parameters: gross floor area, number of months in use, number of PC's, number of students, weekly operating hours, \% of space air conditioned, $\%$ of space heated, on-site cooking facilities (Y/N), mechanically ventilated (Y/N).

- CBECS: key parameters include most of the above-mentioned information because the Energy Star model is largely based upon the CBECS database for rating. Specifically, the energy and related building characteristics are related to classroom spaces, but the data represents the aggregation of all educational facilities that include, for example, universities. 
- Florida FSEC database: The survey includes the following qualitative and sometimes quantitative information: gymnasium, athletic facilities with showers, swimming pool, auditoriums, media centers/computer center, cooking facility, cafeteria, refrigerators or freezers. All of these variables are important as these uses can potentially impact the total energy use by K-12 schools.

- California CEUS: Data analysis based upon the California CEUS databases for schools indicates interesting findings on the EUI and correlations with availability of swimming and climate zones, the design features of windows, glazing, and daylighting, and some correlations of EUI with window features, exterior shading, and daylighting. Other factors not necessarily analyzed in this project might also correlate with the overall EUI of the school buildings.

Although the various databases studied in this project provide a lot of good information as to school energy use and/or window glazing features, and some possible correlations among such parameters, none of the databases is adequate for providing robust information and relational information on classroom energy use, window glazing design, and skylight. This project has developed a list of recommended parameters and information to be included for future efforts.

\section{Energy information:}

- Annual energy use and costs: types of energy use (electricity, natural gas, other fuels), building areas served, equipment types and usage

- Climate: climate zones and weather information

- Services: notable services and equipment that may impact the on-site energy use

\section{Building design and operation information:}

- Building and school type (e.g., high school, middle school, vocational school, and elementary school; portable classrooms, regular classrooms)

- Gross floor area, classroom floor area, number of months in use, number of personal computers (PCs), number of students and faculty, operation schedule (e.g., weekly operating hours, monthly, non-school days), $\%$ of space air conditioned, $\%$ of space heated, ventilation.

- Information about on-site cooking facilities, meals, gymnasium, athletic facilities with showers, swimming pool, hot tubs, auditoriums, media centers/computer center, cafeteria, refrigerators or freezers

- Vintage and retrofits

- Lighting equipment types, control, and operation

- Mechanical systems, control, and operation (e.g., thermostats, humidity problems, central cooling set points, ceiling fans, demand controlled ventilation, light colored roofs, heat pump, HVAC type)

\section{Features of window and daylighting:}

- The design features of windows, glazing, shading, and daylighting. This includes the information on glazing layer, glazing types (tinted, reflective, clear), glazing feature 
(gas-filled, low-e), window frame (wood, metal, etc.), interior shading and types (fixed, movable, none), window/wall area ratios, orientation, exterior shading, and skylight

- Operational characteristics such as operable windows and their use

\section{Conclusion and Recommendations}

Through the review and analysis of this data, it is clear that there are many compounding factors impacting energy use in K-12 school buildings in the U.S., and that there are various challenges in understanding the impact of K-12 classroom energy use associated with design features of window glazing and skylight.

First, the energy data in the existing CEUS databases has, at most, provided the aggregated electricity and/or gas usages for the building establishments that include other school facilities on top of the classroom spaces. Although the percentage of classroom floor area in schools is often available from the databases, there is no additional information that can be used to quantitatively segregate the EUI for classroom spaces. In order to quantify the EUI for classrooms, sub-metering of energy usage by classrooms must be obtained.

Second, magnitudes of energy use for electricity lighting are not attainable from the existing databases, nor are the lighting levels contributed by artificial lighting or daylight. It is impossible to reasonably estimate the lighting energy consumption for classroom areas in the sample of schools studied in this project.

Third, there are many other compounding factors that may as well influence the overall classroom energy use, e.g., ventilation, insulation, system efficiency, occupancy, control, schedules, and weather.

Fourth, although we have examined the school EUI grouped by various factors such as climate zones, window and daylighting design features from the California databases, no statistically significant associations can be identified from the sampled California K-12 schools in the current California CEUS. There are opportunities to expand such analyses by developing and including more powerful CEUS databases in the future.

Finally, a list of parameters is recommended for future database development and for use of future investigation in K-12 classroom energy use, window and skylight design, and possible relations between them. Some of the key parameters include:

- Energy end use data for lighting systems, classrooms, and schools

- Building design and operation including features for windows and daylighting

- Other key parameters and information that would be available to investigate overall energy uses, building and systems' design, their operation, and services provided. 


\section{Acknowledgements}

We would like to acknowledge the National Association of State Energy Officials and Abby Vogen from the Energy Center of Wisconsin supporting this research. We are appreciate the assistance provided by Danny S. Parker and Lixing Gu (Florida Solar Energy Center), Craig Schepp (Energy Center of Wisconsin), Sara Greenwood (The Collaborative for High Performance Schools), Don Lavada (NYSERDA), Satkartar Kinney (LBNL), Mike Apte (LBNL), and the California Energy Commission in this project. The Association of State Energy Research and Technology Transfer Institutions, Inc. (ASERTTI) and the National Association of State Energy Officials (NASEO) with the Department of Energy (DOE) and the EnergySmart Schools Program are conducting a joint project which encompasses applied research, field testing and technology integration. Within this project the Energy Center of Wisconsin (ECW) manages Daylighting research approaches in schools and the dissemination of information. This work was supported by NASEO and by the Assistant Secretary for Energy Efficiency and Renewable Energy, Office of Building Technology, State and Community Programs of the U.S. Department of Energy under Contract No. DE-AC03-76SF00098. 


\section{References}

CalARCH. California Building Energy Reference Tool. http://poet.lbl.gov/calarch/glossary.html\#zone, last visited July 21, 2004.

California Energy Commission. The California Commercial End-Use Survey (CEUS), 1992-1997. More details at: http://poet.lbl.gov/cal-arch/ceus.html.

Callahan, Michael P., Danny S. Parker, Wanda L. Dutton, Janet E.R. McIlvaine. 1997. Energy Efficiency for Florida Educational Facilities: The 1996 Energy Survey of Florida Schools. Final Report (FSEC-CR-951-97). July 1997, Prepared by Florida Solar Energy Center, 1679 Clearlake Rd. Cocoa, FL 32922-5703.

Energy Information Administration (EIA). 2001. 1999 Commercial Buildings Energy Consumption Survey (CBECS). http://www.eia.doe.gov/emeu/cbecs/.

EPA. Energy Star Schools, http://yosemite1.epa.gov/r10/oi.nsf/webpage/energystarschools, last visited July 22, 2004.

Hinge, A., J. Rutherford, D. Abrey, J. daSilva, and E. Titus. 2002. Back to School on Energy Benchmarking. Proceedings of the 2002 ACEEE Summer Study on Energy Efficiency in Buildings: 9.197-9.210. Washington, D.C.: American Council for an Energy-Efficient Economy.

Kinney, S., and M.A. Piette. 2003. California Commercial Building Energy Benchmarking, Final Report to CEC. July 2003.

PG\&E. 1999. 1999 Commercial Building Survey Report. http://www.pge.com/003 save energy/003b bus/pdf/CEUS 1999.pdf

Piette, M.A., and N. Bourassa. 2001. "Final Report on Swimming Pools adjustment for K-12 Schools Energy Star Rating." Memo to R. Rose and T. Hicks, EPA; and M. Brook, CEC.

The Wisconsin K-12 Energy Education Program (KEEP). 1997-98 WEI-2 school survey data. http://www.uwsp.edu/cnr/wcee/keep/audit/average.htm 


\section{Appendix A}

\section{Design features relevant to window, glazing, skylight, and shading (developed from the California CEUS databases)}

The following tables present the occurrence of design features relevant to glazing (layer, type, feature), window (frame material), availability of shading (interior, exterior), and availability of skylight in the surveyed California K-12 schools.

In each of the following tables, the frequency column represents the number of observations for a specific design feature as specified in the row, while the percent column represents the percentage of total of observations for that specific design feature. Missing numbers are noted as "." and represent that there is no recorded information available in the database for the inclusion in analysis.

\begin{tabular}{|r|r|r|r|r|}
\hline \multicolumn{7}{|c|}{ Layers of Glazing } \\
\hline $\begin{array}{r}\text { \# of } \\
\text { Glazing } \\
\text { Layer }\end{array}$ & Frequency & Percent & $\begin{array}{r}\text { Cumulative } \\
\text { Frequency }\end{array}$ & $\begin{array}{r}\text { Cumulative } \\
\text { Percent }\end{array}$ \\
\hline Missing & 1 &. &. & \\
\hline $\mathbf{1}$ & 100 & 95.24 & 100 & 95.24 \\
\hline $\mathbf{2}$ & 5 & 4.76 & 105 & 100.00 \\
\hline
\end{tabular}

\begin{tabular}{|l|r|r|r|r|}
\hline \multicolumn{5}{|c|}{ Glazing Type (Clear, Reflective, Tinted) } \\
\hline GTYPE & Frequency & Percent & $\begin{array}{r}\text { Cumulative } \\
\text { Frequency }\end{array}$ & $\begin{array}{r}\text { Cumulative } \\
\text { Percent }\end{array}$ \\
\hline Missing & 1 & $\cdot$ & $\cdot$ & \\
\hline Clear & 60 & 57.14 & 60 & 57.14 \\
\hline Reflective & 4 & 3.81 & 64 & 60.95 \\
\hline Tinted & 41 & 39.05 & 105 & 100.00 \\
\hline
\end{tabular}




\begin{tabular}{|l|r|r|r|r|}
\hline \multicolumn{5}{|c|}{ Glass Features (None, Low-E, Gas-Filled) } \\
\hline GFEATURE & Frequency & Percent & $\begin{array}{r}\text { Cumulative } \\
\text { Frequency }\end{array}$ & $\begin{array}{r}\text { Cumulative } \\
\text { Percent }\end{array}$ \\
\hline Missing & 59 & $\cdot$ & $\cdot$ & \\
\hline Gas-filled & 1 & 2.13 & 1 & 2.13 \\
\hline $\begin{array}{l}\text { None of } \\
\text { above }\end{array}$ & 46 & 97.87 & 47 & 100.00 \\
\hline
\end{tabular}

\begin{tabular}{|l|r|r|r|r|}
\hline \multicolumn{7}{|c|}{ Frame (Metal, Wood) } \\
\hline GFRAME & Frequency & Percent & $\begin{array}{r}\text { Cumulative } \\
\text { Frequency }\end{array}$ & $\begin{array}{r}\text { Cumulative } \\
\text { Percent }\end{array}$ \\
\hline Missing & 1 &. &. & \\
\hline Metal & 85 & 80.95 & 85 & 80.95 \\
\hline Wood & 20 & 19.05 & 105 & 100.00 \\
\hline
\end{tabular}

\begin{tabular}{|l|r|r|r|r|}
\hline \multicolumn{7}{|c|}{ Interior Shading } \\
\hline GSHADE & Frequency & Percent & $\begin{array}{r}\text { Cumulative } \\
\text { Frequency }\end{array}$ & $\begin{array}{r}\text { Cumulative } \\
\text { Percent }\end{array}$ \\
\hline Missing & 61 &. &. & \\
\hline Fixed & 1 & 2.22 & 1 & 2.22 \\
\hline Movable & 37 & 82.22 & 38 & 84.44 \\
\hline $\begin{array}{l}\text { Not } \\
\text { available }\end{array}$ & 7 & 15.56 & 45 & 100.00 \\
\hline
\end{tabular}

\begin{tabular}{|l|r|r|r|r|}
\hline \multicolumn{5}{|c|}{ Exterior Shading Availability (Yes, No) } \\
\hline Geshade & Frequency & Percent & $\begin{array}{r}\text { Cumulative } \\
\text { Frequency }\end{array}$ & $\begin{array}{r}\text { Cumulative } \\
\text { Percent }\end{array}$ \\
\hline No & 71 & 66.98 & 71 & 66.98 \\
\hline Yes & 35 & 33.02 & 106 & 100.00 \\
\hline
\end{tabular}




\begin{tabular}{|l|r|r|r|r|}
\hline \multicolumn{5}{|c|}{ Skylight Availability (Yes, No) } \\
\hline RSKY & Frequency & Percent & $\begin{array}{r}\text { Cumulative } \\
\text { Frequency }\end{array}$ & $\begin{array}{r}\text { Cumulative } \\
\text { Percent }\end{array}$ \\
\hline Missing & 59 &. &. & \\
\hline No & 43 & 91.49 & 43 & 91.49 \\
\hline Yes & 4 & 8.51 & 47 & 100.00 \\
\hline
\end{tabular}

Appendix A - iii 


\section{Appendix B}

\section{Energy Use Intensity Grouped by Swimming Pool Types}

\begin{tabular}{|c|c|c|c|c|c|c|}
\hline Schools & EUI & $\begin{array}{c}\text { Sample } \\
\text { Size of } \\
\text { Schools }\end{array}$ & Mean & Std Dev & Min & Max \\
\hline $\begin{array}{c}\text { Without } \\
\text { Pools }\end{array}$ & Electricity EUI (kBtu/ft2yr) & 75 & 33.2 & 35.9 & 2.6 & 190.5 \\
\cline { 2 - 7 } & Gas EUI (kBtu/ft2yr) & 33 & 26.7 & 17.1 & 6.2 & 84.3 \\
\hline \multirow{2}{\text{WithPools}}{} & Electricity EUI (kBtu/ft2yr) & 18 & 38.1 & 31.6 & 4.8 & 116.3 \\
\cline { 2 - 7 } & Gas EUI (kBtu/ft2yr) & 4 & 63.4 & 31.8 & 37.6 & 108.7 \\
\hline $\begin{array}{c}\text { With Hot } \\
\text { Tub }\end{array}$ & Electricity EUI (kBtu/ft2yr) & 12 & 63.0 & 42.4 & 17.9 & 143.4 \\
\cline { 2 - 7 } & Gas EUI (kBtu/ft2yr) & 0 & $\cdot$ & $\cdot$ & $\cdot$ &. \\
\hline
\end{tabular}

\section{Energy Use Intensity Grouped by Climate Zones and Swimming Pool Types}

\section{Climate zone: 1-N Coast; 3-C Coast, 2-S Coast; 4-Inland}

\begin{tabular}{|c|c|c|c|c|c|c|c|}
\hline Schools & $\begin{array}{l}\text { Climate } \\
\text { Zone }\end{array}$ & EUI & $\begin{array}{l}\text { Sample } \\
\text { Size of } \\
\text { Schools }\end{array}$ & Mean & Std Dev & Min & Max \\
\hline \multirow{6}{*}{$\begin{array}{c}\text { Without } \\
\text { Pool }\end{array}$} & 1 & Electricity EUI (kBtu/ft2yr) & 21 & 27.8 & 29.0 & 7.3 & 130.6 \\
\hline & & Gas EUI (kBtu/ft2yr) & 19 & 30.8 & 20.0 & 7.6 & 84.3 \\
\hline & 2 & $\begin{array}{c}\text { Electricity EUI (kBtu/ft2yr) } \\
\text { Gas EUI (kBtu/ft2yr) }\end{array}$ & $\begin{array}{c}29 \\
0\end{array}$ & 39.1 & $\begin{array}{c}40.8 \\
.\end{array}$ & 2.6 & 160.9 \\
\hline & 3 & Electricity EUI (kBtu/ft2yr) & 20 & 25.1 & 12.2 & 10.1 & 57.4 \\
\hline & & Gas EUI (kBtu/ft2yr) & 14 & 21.2 & 10.7 & 6.2 & 39.1 \\
\hline & 4 & $\begin{array}{c}\text { Electricity EUI }(\mathrm{kBtu} / \mathrm{ft} 2 \mathrm{yr}) \\
\text { Gas EUI }(\mathrm{kBtu} / \mathrm{ft} 2 \mathrm{yr})\end{array}$ & $\begin{array}{l}5 \\
0\end{array}$ & 54.2 & 76.9 & 2.6 & 190.5 \\
\hline \multirow[t]{3}{*}{ With Pool } & 1 & $\begin{array}{c}\text { Electricity EUI (kBtu/ft2yr) } \\
\text { Gas EUI (kBtu/ft2yr) }\end{array}$ & $\begin{array}{l}5 \\
4\end{array}$ & $\begin{array}{l}32.9 \\
63.4\end{array}$ & $\begin{array}{c}9.8 \\
31.8\end{array}$ & $\begin{array}{l}19.1 \\
37.6\end{array}$ & $\begin{array}{c}45.9 \\
108.7\end{array}$ \\
\hline & 2 & $\begin{array}{c}\text { Electricity EUI (kBtu/ft2yr) } \\
\text { Gas EUI (kBtu/ft2yr) }\end{array}$ & $\begin{array}{c}10 \\
0\end{array}$ & 35.6 & 32.2 & 4.8 & 99.4 \\
\hline & 3 & $\begin{array}{c}\text { Electricity EUI (kBtu/ft2yr) } \\
\text { Gas EUI (kBtu/ft2yr) }\end{array}$ & $\begin{array}{l}3 \\
0\end{array}$ & 55.0 & 55.7 & 7.4 & 116.3 \\
\hline \multirow[t]{2}{*}{ With Hot Tub } & 2 & $\begin{array}{c}\text { Electricity EUI }(\mathrm{kBtu} / \mathrm{ft} 2 \mathrm{yr}) \\
\text { Gas EUI }(\mathrm{kBtu} / \mathrm{ft} 2 \mathrm{yr})\end{array}$ & $\begin{array}{l}9 \\
0\end{array}$ & 68.4 & 46.6 & 17.9 & 143.4 \\
\hline & 4 & $\begin{array}{c}\text { Electricity EUI (kBtu/ft2yr) } \\
\text { Gas EUI (kBtu/ft2yr) }\end{array}$ & $\begin{array}{l}2 \\
0\end{array}$ & 31.9 & 4.8 & 28.5 & 35.3 \\
\hline
\end{tabular}




\section{Appendix C}

\section{Energy Use Intensity Grouped by Window Features}

\begin{tabular}{|c|c|c|c|c|c|c|}
\hline $\begin{array}{c}\text { Layers of } \\
\text { glazing }\end{array}$ & EUI & $\begin{array}{c}\text { Sample Size } \\
\text { of Schools }\end{array}$ & Mean & Std Dev & Min & Max \\
\hline \multirow{2}{*}{1} & Electricity EUI (kBtu/ft2yr) & 72 & 31.2 & 33.9 & 2.6 & 190.5 \\
\cline { 2 - 7 } & Gas EUI (kBtu/ft2yr) & 32 & 27.0 & 17.3 & 6.2 & 84.3 \\
\hline \multirow{2}{*}{2} & Electricity EUI (kBtu/ft2yr) & 2 & 80.4 & 79.5 & 24.2 & 136.6 \\
\cline { 2 - 7 } & Gas EUI (kBtu/ft2yr) & 1 & 17.5 & $\cdot$ & 17.5 & 17.5 \\
\hline
\end{tabular}

\begin{tabular}{|c|c|c|c|c|c|c|}
\hline Glazing type & EUI & $\begin{array}{c}\text { Sample Size } \\
\text { of Schools }\end{array}$ & Mean & Std Dev & Min & Max \\
\hline \multirow{2}{*}{ Clear } & Electricity EUI (kBtu/ft2yr) & 45 & 25.5 & 25.4 & 2.6 & 130.6 \\
\cline { 2 - 7 } & Gas EUI (kBtu/ft2yr) & 24 & 29.7 & 18.4 & 6.2 & 84.3 \\
\hline \multirow{2}{*}{ Reflective } & Electricity EUI (kBtu/ft2yr) & 2 & 46.0 & 16.1 & 34.6 & 57.4 \\
\cline { 2 - 7 } & Gas EUI (kBtu/ft2yr) & 1 & 39.1 & $\cdot$ & 39.1 & 39.1 \\
\hline \multirow{2}{*}{ Tinted } & Electricity EUI (kBtu/ft2yr) & 27 & 43.4 & 47.4 & 5.3 & 190.5 \\
\cline { 2 - 7 } & Gas EUI (kBtu/ft2yr) & 8 & 16.2 & 6.9 & 7.6 & 26.6 \\
\hline
\end{tabular}

\begin{tabular}{|c|c|c|c|c|c|c|}
\hline $\begin{array}{c}\text { Features } \\
\text { (None, Low-E, } \\
\text { Gas-Filled) }\end{array}$ & EUI & $\begin{array}{c}\text { Sample Size } \\
\text { of Schools }\end{array}$ & Mean & Std Dev & Min & Max \\
\cline { 2 - 7 } Gas-filled & Electricity EUI (kBtu/ft2yr) & 1 & 24.2 &. & 24.2 & 24.2 \\
& Gas EUI (kBtu/ft2yr) & 1 & 17.5 &. & 17.5 & 17.5 \\
\cline { 2 - 7 } None & Electricity EUI (kBtu/ft2yr) & 40 & 26.8 & 22.4 & 7.3 & 130.6 \\
& Gas EUI (kBtu/ft2yr) & 32 & 27.0 & 17.3 & 6.2 & 84.3 \\
\hline
\end{tabular}

\begin{tabular}{|c|c|c|c|c|c|c|}
\hline \multirow{3}{*}{ Frame type } & EUI & $\begin{array}{c}\text { Sample Size } \\
\text { of Schools }\end{array}$ & Mean & Std Dev & Min & Max \\
\cline { 2 - 7 } Metal & Electricity EUI (kBtu/ft2yr) & 59 & 35.1 & 39.0 & 2.6 & 190.5 \\
& Gas EUI (kBtu/ft2yr) & 24 & 24.7 & 16.3 & 6.2 & 84.3 \\
\cline { 2 - 7 } Wood & Electricity EUI (kBtu/ft2yr) & 15 & 22.5 & 14.3 & 7.6 & 64.5 \\
& Gas EUI (kBtu/ft2yr) & 9 & 31.9 & 19.2 & 14.4 & 73.4 \\
\hline
\end{tabular}




\begin{tabular}{|c|c|c|c|c|c|c|}
\hline \multirow{2}{*}{$\begin{array}{c}\text { Interior } \\
\text { Shading }\end{array}$} & EUI & $\begin{array}{c}\text { Sample Size } \\
\text { of Schools }\end{array}$ & Mean & Std Dev & Min & Max \\
\cline { 2 - 7 } Fixed & Electricity EUI (kBtu/ft2yr) & 1 & 19.6 &. & 19.6 & 19.6 \\
& Gas EUI (kBtu/ft2yr) & 0 &. &. &. &. \\
\cline { 2 - 7 } Movable & Electricity EUI (kBtu/ft2yr) & 34 & 26.2 & 21.6 & 7.3 & 130.6 \\
& Gas EUI (kBtu/ft2yr) & 28 & 27.0 & 17.3 & 6.2 & 84.3 \\
\cline { 2 - 7 } None & Electricity EUI (kBtu/ft2yr) & 4 & 35.8 & 34.5 & 12.5 & 87.1 \\
& Gas EUI (kBtu/ft2yr) & 4 & 18.2 & 9.0 & 7.6 & 28.0 \\
\hline
\end{tabular}

\begin{tabular}{|c|c|c|c|c|c|c|}
\hline $\begin{array}{c}\text { Exterior } \\
\text { Shading (Y/N) }\end{array}$ & EUI & $\begin{array}{c}\text { Sample Size } \\
\text { of Schools }\end{array}$ & Mean & Std Dev & Min & Max \\
\cline { 2 - 7 } N & Electricity EUI (kBtu/ft2yr) & 47 & 38.7 & 42.6 & 2.6 & 190.5 \\
& Gas EUI (kBtu/ft2yr) & 12 & 30.1 & 24.9 & 6.2 & 84.3 \\
\cline { 2 - 7 } Y & Electricity EUI (kBtu/ft2yr) & 28 & 24.0 & 17.1 & 7.3 & 87.1 \\
& Gas EUI (kBtu/ft2yr) & 21 & 24.7 & 10.9 & 7.6 & 53.8 \\
\hline
\end{tabular}

\begin{tabular}{|c|c|c|c|c|c|c|}
\hline \multirow{3}{*}{\begin{tabular}{c} 
Skylight \\
\multirow{2}{*}{ N }
\end{tabular}} & EUI & $\begin{array}{c}\text { Sample Size } \\
\text { of Schools }\end{array}$ & Mean & Std Dev & Min & Max \\
\cline { 2 - 7 } & Electricity EUI (kBtu/ft2yr) & 37 & 27.7 & 23.0 & 7.3 & 130.6 \\
Gas EUI (kBtu/ft2yr) & 29 & 26.8 & 18.0 & 6.2 & 84.3 \\
\cline { 2 - 7 } Y & Electricity EUI (kBtu/ft2yr) & 4 & 18.1 & 6.4 & 11.2 & 24.2 \\
& Gas EUI (kBtu/ft2yr) & 4 & 25.9 & 10.9 & 15.8 & 37.7 \\
\hline
\end{tabular}


LBNL-54233 